\title{
Dopamine D-1 and D-2 Receptor Antagonists Potentiate Analgesic and Motor Effects of Morphine
}

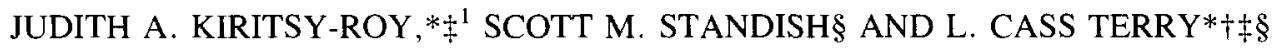 \\ Departments of *Neurology and $†$ Physiology \\ and $¥$ Institute of Gerontology, University of Michigan, Ann Arbor, MI 48109 \\ and §Neuroendocrine Research Laboratory, Veterans Administration Medical Center, Ann Arbor, MI 48105
}

Received 27 June 1988

\begin{abstract}
KIRITSY-ROY, J. A., S. M. STANDISH AND L. C. TERRY. Dopamine D-I and D-2 receptor antagonists potentiate analgesic and motor effects of morphine. PHARMACOL BIOCHEM BEHAV 32(3) 717-721, 1989. - To examine the role of dopamine receptor subtypes mediating analgesic and motor responses to opioids, rats were pretreated with either saline or a selective D-1 or D-2 dopamine receptor antagonist $10 \mathrm{~min}$ prior to morphine $(12 \mathrm{mg} / \mathrm{kg} \mathrm{IP})$. Analgesic response latency was determined using the hot plate test $\left(52.5^{\circ} \mathrm{C}\right.$ and $55^{\circ} \mathrm{C}$ ), and catalepsy was assessed using the abnormal posture test. Morphine increased analgesic response latency to $44.5 \pm 7.9 \%$ of the maximum possible response, but had no cataleptic effect in the abnormal posture test. Pretreatment with either the D-1 antagonist, SCH $23390(50-100 \mu \mathrm{g} / \mathrm{kg})$, or the D-2 antagonist, eticlopride $(20-150 \mu \mathrm{g} / \mathrm{kg})$, potently enhanced morphine analgesia as measured on the $52.5^{\circ} \mathrm{C}$ hot plate. Peak analgesic responses to morphine increased to $100 \pm 0 \%$ and $91.9 \pm 7.5 \%$ of maximum with the highest doses of SCH 23390 and eticlopride, respectively. These treatments also produced catalepsy. Increasing the hot plate temperature to $55^{\circ} \mathrm{C}$ reduced response latency in groups treated with either dopamine receptor antagonist plus morphine. This indicates that the animals were capable of responding at a shorter latency and demonstrates that motor impairment cannot account for potentiation of morphine analgesia by D-1 and D-2 antagonists at $52.5^{\circ} \mathrm{C}$. These results show that the relationship between dopamine and opioids with respect to analgesic and motor systems involves both dopamine receptor subtypes.
\end{abstract}

$\begin{aligned} & \text { Morphine } \\ & \text { Catalepsy }\end{aligned}$
SCH $23390 \quad$ Eticlopride Analgesia Dopamine receptors

BRAIN dopaminergic systems have been widely implicated in many of the pharmacologic effects of opioids. Manipulations which alter the activity of dopamine in the central nervous system frequently shift analgesia dose-response curves for morphine and other opioid drugs. For example, the dopamine antagonist, haloperidol, while not analgesic itself, potentiated the analgesic response to morphine in mice (7) and in rats (13). Other dopamine receptor blockers, such as spiroperidol, clothiapine and perphenazine, reduced the analgesic $\mathrm{ED}_{50}$ for morphine in mice (27). Destruction of dopamine neurons by treatment with 6-hydroxydopamine enhanced morphine analgesia in both the hot plate and tail compression tests in rats (21). Although the dopamine receptor agonist, apomorphine, had no effect on morphine-induced antinociception in naive rats, it blocked completely morphine analgesia in chronically haloperidol-treated rats (13). Similarly, apomorphine shifted to the right the dose-response curve for morphine-induced antinociception in naive mice (27). Thus, it appears that the opioid-sensitive pain pathway is under the inhibitory influence of dopamine.
In recent years, compelling evidence has accumulated to allow classification of CNS dopamine receptors into two distinct subtypes, designated D-1 and D-2, on the basis of biochemical and pharmacological criteria. It is generally agreed that the D-1 receptor is coupled to adenylate cyclase, and stimulation causes increased production of cAMP (14). Stimulation of the D-2 receptor has either no effect on CAMP formation or reduces $\mathrm{cAMP}$ accumulation induced by D- 1 agonists (26). The recent availability of selective agonists and antagonists for dopamine D-1 and D-2 receptors provides powerful tools which can be used to determine the roles of these receptor subtypes in mediating some of the physiological and pharmacological effects of dopamine in the CNS. The experiments described here were undertaken to provide insight into the role of specific dopamine receptor subtypes in mediating analgesic and motor responses to morphine in rats. $\mathrm{SCH}$ 23390 was employed as a selective D-1 antagonist $(11,12)$, and eticlopride was used to produce antagonism at the D-2 receptor (6). The results indicate that both D-1 and D-2 receptors are involved in analgesic and motor effects of opioids.

\footnotetext{
${ }^{1}$ Requests for reprints should be addressed to Judith A. Kiritsy-Roy, Ph.D., Veterans Administration Medical Center (151), 2215 Fuller Road, Ann Arbor, MI 48105 .
} 


\section{METHOD}

Adult male Sprague-Dawley rats (Harlan Ind., Indianapolis, IN) weighing $306 \pm 5 \mathrm{~g}(\mathrm{n}=123)$ were used in all experiments. Animals were housed in groups of 4-5 in the animal quarters, with automatically controlled lighting (lights on from 7:00 a.m.--7:00 p.m. ), temperature $\left(22^{\circ} \mathrm{C}\right)$ and humidity. Food and water were available ad lib except the night before the experiment, when subjects were food and water deprived for 16-20 hours. The rats were moved from the animal facility to the laboratory on the morning of experimentation.

Analgesia was assessed using an adaptation of the hot plate procedure described by O'Callaghan and Holtzman (17). Their studies demonstrated that reduction of hot plate temperature from $55^{\circ} \mathrm{C}$ was necessary to achieve optimum sensitivity for detection of analgesic activity of opioid-related drugs. The device consisted of a copper surface maintained at a temperature of either $52.5^{\circ} \mathrm{C}$ or $55^{\circ} \mathrm{C}$. A clear Plexiglas cylinder $10^{\prime \prime}$ in height with a $12^{\prime \prime}$ diameter confined the rat to the heated surface. Endpoints used to determine reaction latency were licking of a hindpaw or jumping to the rim of the cylinder. A maximum cut-off time of $45 \mathrm{sec}$ was used to prevent tissue trauma to analgesic rats. Three baseline latency determinations on the hot plate were obtained at 5-min intervals before administration of drug, and these were averaged to give a mean baseline latency (B). Posttreatment response latencies ( $R$ ) were observed every $5 \mathrm{~min}$ for $30 \mathrm{~min}$, and a final determination was made at $40 \mathrm{~min}$. Analgesic responses are calculated as the percent of the maximum possible response (\%MPR), defined as $[(\mathrm{R}-\mathrm{B}) /(45-\mathrm{B})] \times 100 \%$.

The presence of a state of catalepsy was detected using the abnormal posture test (8). This test involved placement of the hindpaw of the rat upon a $3-\mathrm{cm}$ high cork. Latency to step-down was recorded before and at intervals after drug treatment. A maximum cut-off time of $45 \mathrm{sec}$ was used, and cataleptic responses were calculated using the same formula for \%MPR described above for analgesic responses.

All drugs were administered IP, and dosages are given as weight of the salt form. SCH 23390 hydrochloride (RBI, Natick, MA) was initially dissolved in a minimum volume of $10 \%$ acetic acid and diluted with saline. Morphine sulfate (Wyeth, Philadelphia, PA, $10 \mathrm{mg} / \mathrm{ml}$ ) was administered at a dose of $12 \mathrm{mg} / \mathrm{kg}$. Either SCH 23390 hydrochloride or eticlopride hydrochloride (RBI, Natick. MA) was injected $10 \mathrm{~min}$ before morphine in a volume of $1 \mathrm{ml} / \mathrm{kg}$.

Data were analyzed by ANOVA using SAS on an IBM PC/AT. Differences between treatments were considered significant for $p<0.05$ as determined with Duncan's multiple comparisons test.

\section{RESULTS}

\section{Effect of SCH 23390 on Morphine Analgesia}

Injection of saline $(1 \mathrm{ml} / \mathrm{kg})$ had no effect on response latency on the $52.5^{\circ} \mathrm{C}$ hot plate. Morphine $(12 \mathrm{mg} / \mathrm{kg})$ produced a significant increase in latency compared to saline control (Fig. 1A). The analgesic effect of morphine peaked by $30 \mathrm{~min}$ after treatment and was antagonized by naloxone $(1 \mathrm{mg} / \mathrm{kg})$ injected 10 min before morphine (data not shown). The D-1 receptor antagonist, SCH 23390, potentiated the analgesic response to morphine $(12 \mathrm{mg} / \mathrm{kg}$ ) (Fig. 1A). Potentiation of morphine-induced analgesia by $\mathrm{SCH} 23390$ was dose-related over the dose range of 50-100 $\mu \mathrm{g} / \mathrm{kg}$. These doses of SCH 23390 administered alone to groups of rats had little antinociceptive activity, although a higher dose of $400 \mu \mathrm{g} / \mathrm{kg}$ produced a transient analgesic response that peaked at $15 \mathrm{~min}$ and returned to baseline by $30 \mathrm{~min}$ (Fig. 1B).

Effect of Eticlopride on Morphine Analgesia

The selective D-2 antagonist, eticlopride, produced dose-
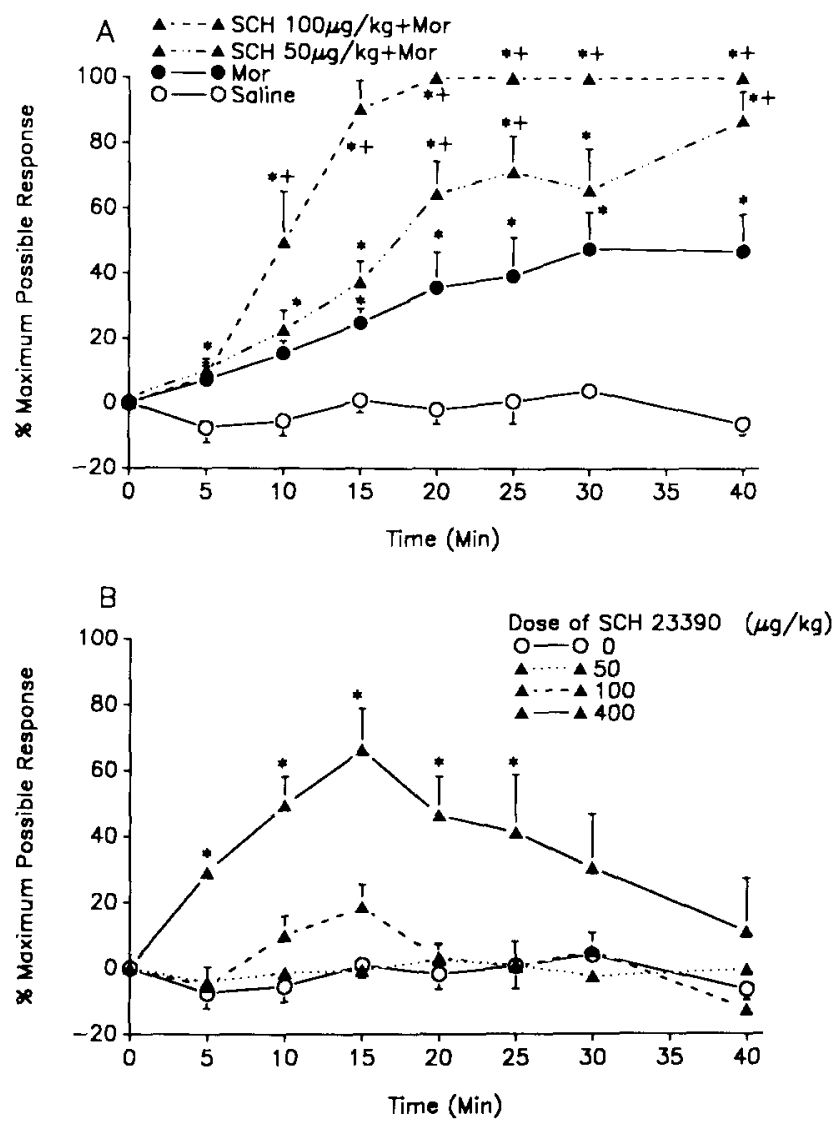

FIG. 1. Analgesic responses on the $52.5^{\circ} \mathrm{C}$ hot plate following administration of SCH 23390 (SCH) in combination with morphine (Mor) (A) or alone (B). (A) SCH ( $100 \mu \mathrm{g} / \mathrm{kg}, \mathrm{n}=7$ or $50 \mu \mathrm{g} / \mathrm{kg}, \mathrm{n}=6)$ was injected 10 min before Mor $(12 \mathrm{mg} / \mathrm{kg})$, which was injected at Time $=0$. Additional groups of rats received saline injection $10 \mathrm{~min}$ before saline $(n=6)$ or Mor (12 $\mathrm{mg} / \mathrm{kg}, \mathrm{n}=17$ ) at Time $=0$. (B) Doses of $\mathrm{SCH}$ were injected in groups of 6 rats per dose at Time $=0$. Three baseline latency determinations were obtained at 5 -min intervals before the pretreatment with saline or $\mathrm{SCH}$ and these were averaged. The average baseline latency did not differ among groups and was $10.4 \pm 0.4 \mathrm{sec}$. Analgesic responses are expressed as mean percent of the maximum possible response \pm SEM (45 sec cut-off). ${ }^{*} p<0.05$ compared to saline; ${ }^{+} p<0.05$ compared to Mor.

related potentiation of the analgesic effect of morphine (Fig. 2A). The peak analgesic effect of morphine $(12 \mathrm{mg} / \mathrm{kg})$ increased from approximately $45 \%$ MPR to $69 \%$ after $75 \mu \mathrm{g} / \mathrm{kg}$ and to $92 \%$ after $150 \mu \mathrm{g} / \mathrm{kg}$ eticlopride. A smaller dose of eticlopride $(20 \mu \mathrm{g} / \mathrm{kg})$ had no significant effect on morphine-induced analgesia (data not shown). Doses of eticlopride that potentiated the morphine response were themselves completely devoid of analgesic activity, although a higher dose $(300 \mu \mathrm{g} / \mathrm{kg})$ produced a small analgesic response (Fig. 2B).

Cataleptic Responses to Morphine Following Pretreatment With D-1 or D-2 Antagonists

Administration of morphine (12 $\mathrm{mg} / \mathrm{kg}$ ) had no apparent cataleptic effect up to $30 \mathrm{~min}$ after treatment, as assessed by the abnormal posture test (Fig. 3A). SCH $23390(100 \mu \mathrm{g} / \mathrm{kg}$ ) alone produced no significant change in cataleptic behavior until $40 \mathrm{~min}$ after its administration (Fig. 3A). Similarly, the small cataleptic 

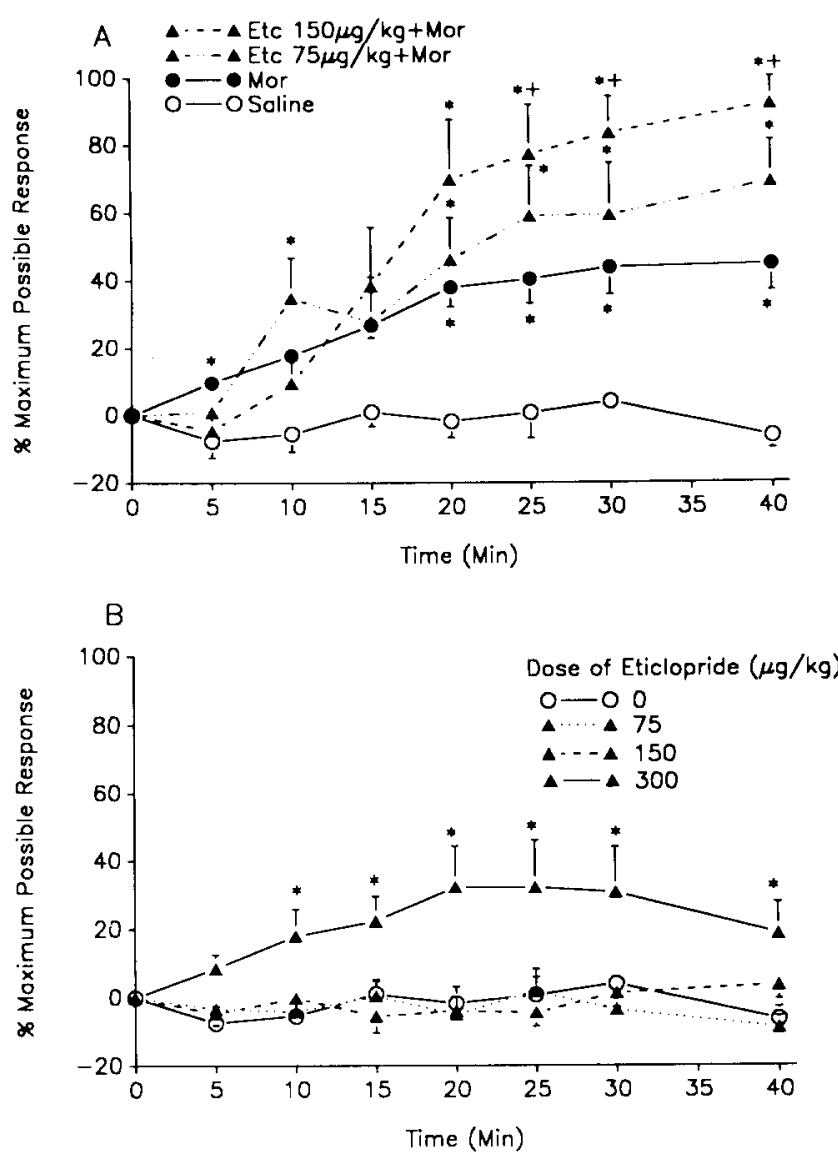

FIG. 2. Analgesic responses on the $52.5^{\circ} \mathrm{C}$ hot plate following administration of eticlopride (Etc) in combination with morphine (Mor) (A) or alone (B). (A) Etc $(75 \mu \mathrm{g} / \mathrm{kg}, \mathrm{n}=7$ or $150 \mu \mathrm{g} / \mathrm{kg}, \mathrm{n}=7$ ) was injected 10 $\min$ before Mor $(12 \mathrm{mg} / \mathrm{kg})$, which was injected at Time $=0$. Additional groups of rats received a saline injection 10 min before saline $(n=6)$ or Mor $(n=17)$ at Time $=0$. (B) Doses of Etc were injected in groups of 5-6 rats at Time $=0$. Baseline and response latencies were determined as described in the legend to Fig. $1 .{ }^{*} p<0.05$ compared to saline: ${ }^{+} p<0.05$ compared to Mor.

response to eticlopride $(150 \mu \mathrm{g} / \mathrm{kg}$ ) was delayed until $30-40 \mathrm{~min}$ posttreatment (Fig. 3B). Pretreatment of rats with these same doses of SCH 23390 (Fig. 3A) or eticlopride (Fig. 3B) $10 \mathrm{~min}$ prior to morphine $(12 \mathrm{mg} / \mathrm{kg})$ elicited profound cataleptic behavior. Enhancement was noted by $15 \mathrm{~min}$ after morphine, and subsequently reached nearly $100 \%$ MPR with either dopamine antagonist.

\section{Effect of Thermal Stimulus Intensity on D-1/D-2 Antagonist- Enhanced Morphine Analgesia}

Since the hot plate test for analgesia requires the animal to perform a coordinated motor response, treatments which produce motor impairment might appear as analgesic. To determine if animals treated with morphine plus either SCH 23390 or eticlopride were capable of initiating the appropriate motor response when tested for analgesia, groups of rats were tested on the hot plate set at a higher temperature $\left(55^{\circ} \mathrm{C}\right)$. A decline in reaction latency at $55^{\circ}$ compared to $52.5^{\circ}$ indicates that motor responses are not impaired by the drug treatment (10). As shown in Fig. 4, neither SCH 23390 nor eticlopride administered prior to morphine prolonged response latency on the $55^{\circ} \mathrm{C}$ hot plate compared to the group treated with morphine alone. This contrasts with the pronounced enhancement of morphine analgesia by these drugs at $52.5^{\circ}$, as described above. These results indicate that although the rats become cataleptic with the combined drug treatment, they are capable of responding to the nociceptive stimulus at a latency similar to that seen in animals that are not cataleptic.

\section{DISCUSSION}

These studies were designed to examine the involvement of D-1 and D-2 dopamine receptor subtypes mediating analgesic and motor effects of morphine in rats. We used potent and selective D-1 and D-2 receptor antagonist drugs in combination with morphine and found that antagonism of either dopamine receptor subtype potentiates morphine analgesia and produces profound catalepsy. Previous reports have described potentiation of opioid effects by D-2 dopamine receptor antagonists. Haloperidol, spiroperidol, clothiapine and perphenazine have been reported to enhance opioid analgesia in rats and mice $(7,27)$. However, until recently, the lack of selective D-1 receptor antagonists has precluded direct assessment of the significance of this receptor in dopaminergic function.

SCH 23390 binds with high affinity to brain dopamine receptors, with a $K_{d}$ less than $1 \mathrm{nM}(3,24,25)$. Whereas it inhibits the binding of $\left[{ }^{3} \mathrm{H}\right]$-piflutixol to striatal membranes with a $\mathrm{K}_{\mathrm{i}}$ of 1 to $1.3 \mathrm{nM}(11,16), \mathrm{K}_{\mathrm{i}}$ values for displacement of $\left[{ }^{3} \mathrm{H}\right]$-haloperidol and $\left[{ }^{3} \mathrm{H}\right]$-spiperone binding at $\mathrm{D}-2$ receptors by $\mathrm{SCH} 23390$ are at least one order of magnitude higher, indicating that this benzazepine derivative is selective for the D-I dopamine site. In addition, SCH 23390 potently inhibits dopamine-stimulated cAMP formation in homogenates of striatum with an $\mathrm{ID}_{50}$ of $11 \mathrm{nM}(12)$, but has no effect on pituitary prolactin secretion except at doses in excess of $2.5 \mathrm{mg} / \mathrm{kg}$ IP (1).

Recently, dePaulis et al. (6) reported the synthesis of a potent and selective D-2 receptor antagonist, eticlopride. The eticlopride $\mathrm{IC}_{50}$ for inhibition of $\left[{ }^{3} \mathrm{H}\right]$-spiperone binding to $\mathrm{D}-2$ sites is 0.92 $\mathrm{nM}$ (6) compared to more than $100 \mu \mathrm{M}$ for inhibition of $\left[{ }^{3} \mathrm{H}\right]$ flupenthixol binding to the D-1 receptor (9). Eticlopride also inhibits apomorphine-induced hyperactivity with an $E_{50}$ of 9-12 $\mu \mathrm{g} / \mathrm{kg}$ and stereotypy with an $\mathrm{ED}_{50}$ of $75 \mu \mathrm{g} / \mathrm{kg}(6,15)$. To evaluate the role of D-1 and D-2 dopamine receptors in the opioid analgesic system, we used SCH 23390 and eticlopride at doses which selectively antagonize D-1 and D-2 receptors, respectively.

Both SCH 23390 and eticlopride strongly potentiated the analgesic response to morphine in rats. These effects were dose-related for both drugs. The lower dose of SCH 23390 (50 $\mu \mathrm{g} / \mathrm{kg}$ ) had no analgesic activity when administered alone, but significantly potentiated morphine analgesia; the higher dose $(100$ $\mu \mathrm{g} / \mathrm{kg}$ ) itself produced a small increase in response latency at 20-25 min after its administration. Doses of eticlopride that were completely devoid of analgesic activity on their own also significantly potentiated morphine-induce analgesia. The D-1 antagonist appeared to be somewhat more potent than the D-2 antagonist, since $\mathrm{SCH} 23390(100 \mu \mathrm{g} / \mathrm{kg}$ IP), a dose equivalent to 0.25 $\mu \mathrm{mol} / \mathrm{kg}$, produced maximum analgesia in all rats subsequently treated with morphine $12 \mathrm{mg} / \mathrm{kg}$, whereas the highest dose of eticlopride $(0.4 \mu \mathrm{mol} / \mathrm{kg})$ potentiated the morphine effect to about $90 \%$ of maximum. However, SCH 23390 and eticlopride appear to interact in a qualitatively similar manner with morphine, in spite of their high selectivities for D-1 and D-2 receptors, respectively.

We also found that either SCH 23390 or eticlopride administered in combination with morphine produced strong catalepsy. The cataleptic responses to either dopamine antagonist alone were relatively small, and morphine alone produced no catalepsy at the 

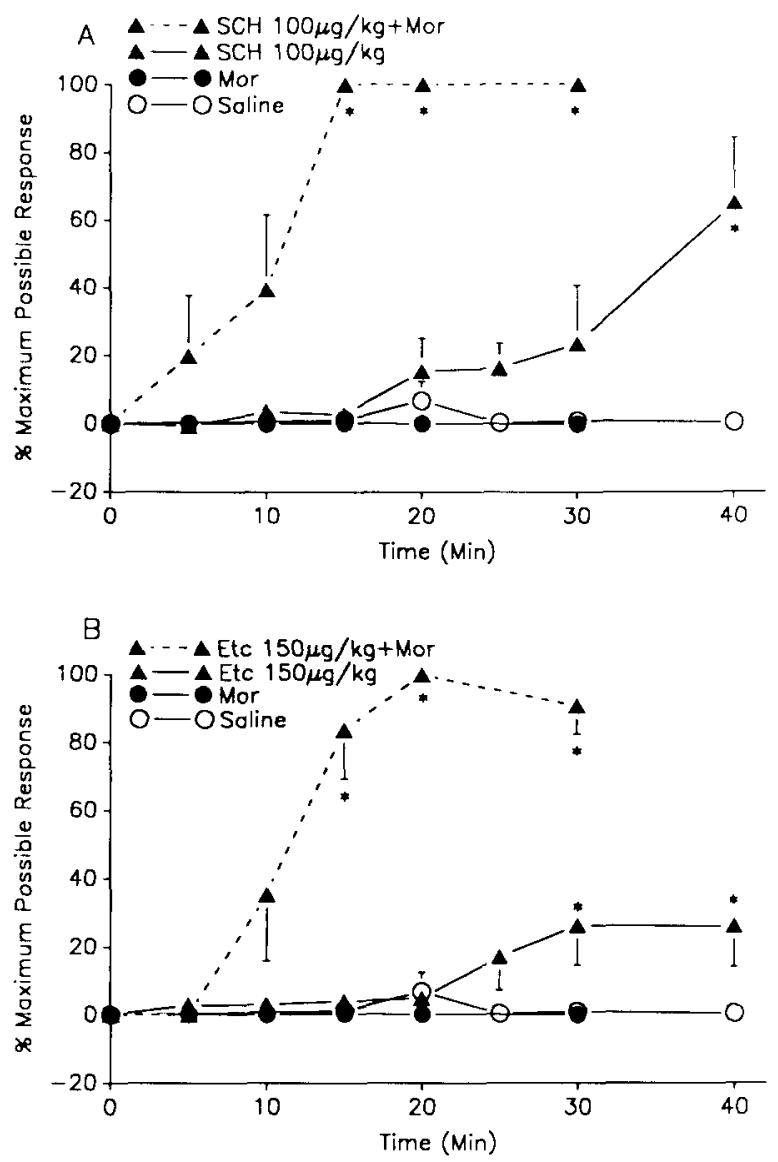

FIG. 3. Cataleptic effects of SCH 23390 (A) and eticlopride (B) alone and in combination with morphine. Catalepsy was assessed using the cork test (8). Three baseline determinations were made at 5 -min intervals before injection of SCH 23390 (SCH) or eticlopride (Etc); morphine (Mor) or saline was injected $10 \mathrm{~min}$ later at Time $=0$. Responses are expressed as mean percent of the maximum possible response \pm SEM (45 sec cut-off) for groups of 5 rats. ${ }^{*} p<0.05$ compared to saline.

dose used $(12 \mathrm{mg} / \mathrm{kg})$. Although higher doses of morphine are reported to induce a cataleptic state, this catalepsy differs qualitatively from that induced by neuroleptic drugs $(5,20)$. Nevertheless, it is thought that opioid systems in the striatum interact with dopaminergic nigrostriatal neurons to alter motor behavior. It has been suggested that opioids reduce nigrostriatal dopamine neurotransmission by presynaptic inhibition of dopamine release (2). Dopamine D-1 and D-2 receptors have been localized in rat neostriatum (4), and our results may reflect interactions between morphine and the D-1 and D-2 antagonists in this brain region.

Because the combination of either SCH 23390 or eticlopride with morphine produced profound inhibition of locomotion, it appeared that the motor effect itself may account for or contribute to the prolonged hot plate response latencies in groups treated with morphine plus a dopamine antagonist. To assess the role of motor impairment, the stimulus intensity was increased from $52.5^{\circ} \mathrm{C}$ to $55^{\circ} \mathrm{C}$. This increase in hot plate temperature resulted in a fall in response latency in groups treated with morphine plus SCH 23390 or eticlopride. In fact, response latencies at $55^{\circ} \mathrm{C}$ in these groups approached those observed in the group treated with morphine alone. This result indicates that although animals treated with morphine and a dopamine receptor antagonist exhibit inhibition of locomotion, they are fully capable of initiating an appropriate

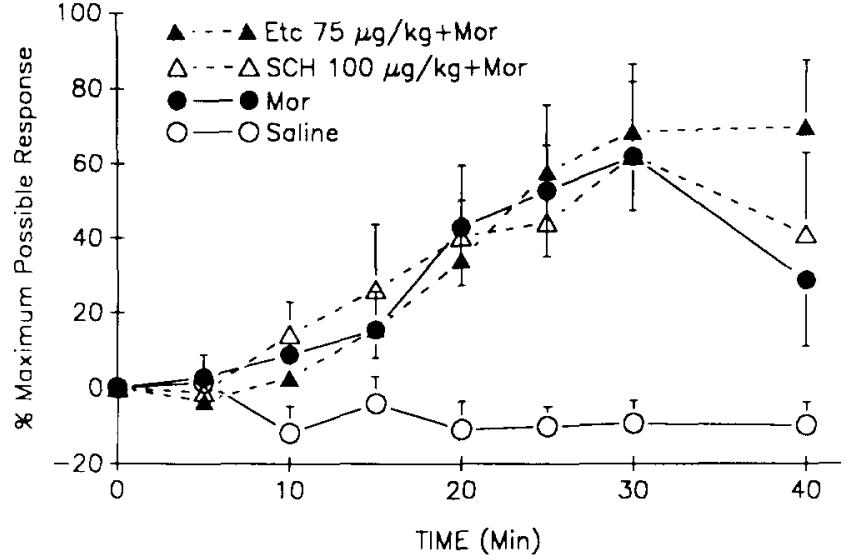

FIG. 4. Analgesic responses to morphine (Mor) on the $55^{\circ} \mathrm{C}$ hot plate following D-1 or D-2 dopamine receptor antagonist pretreatment. Saline, $\mathrm{SCH} 23390(\mathrm{SCH}, 100 \mu \mathrm{g} / \mathrm{kg}, \mathrm{n}=5$ ) or eticlopride (Etc, $75 \mu \mathrm{g} / \mathrm{kg}$ ) was injected $10 \mathrm{~min}$ before Mor $(12 \mathrm{mg} / \mathrm{kg})$, which was injected at Time $=0$. A control group of 5 rats received 2 injections of saline $(1 \mathrm{ml} / \mathrm{kg})$ spaced $10 \mathrm{~min}$ apart. Baseline and response latencies were determined as described in the legend to Fig. 1. The average baseline latency for all groups on the $55^{\circ} \mathrm{C}$ hot plate was $6.5 \pm 0.3 \mathrm{sec}$.

motor response to the stimulus at a latency similar to animals without motor impairment. Although this experiment does not rule out the possibility that dopamine antagonists enhance opioid analgesia by an effect on the motor component of the pain system, it demonstrates that motor impairment per se cannot account for the apparent enhancement of morphine analgesia by D-1 and D-2 antagonists.

It is interesting to note that other behavioral effects of D-1 and D-2 antagonists have been difficult to dissociate, suggesting a functional interaction between the D-1 and D-2 receptors. It has been hypothesized that in brain regions containing both D-1 and D-2 dopamine receptors, D-1 receptors modulate behavioral responses initiated by D-2 receptor stimulation (19). The opioiddopamine synergy reported here may reflect an interaction between these systems in a brain region containing a mixed population of dopamine receptors. Alternatively, since opioids elicit antinociception at several levels of the neuraxis $(18,28)$, morphine may interact with a $D-1$ mechanism at one level and with D-2 pathways at another.

Preliminary studies indicated that D-1 or D-2 receptor agonists did not attenuate the analgesic response to morphine, as might have been predicted from the results with the dopamine antagonists (data not shown). This finding is similar to that reported by Kamata and co-workers (13), which shows that apomorphine had no effect on morphine analgesia except in rats treated chronically with haloperidol. The inability of dopamine agonists to modulate opioid analgesia could be interpreted in several ways. 1) Dopamine receptor antagonists might produce their effects by a nondopaminergic mechanism. Although SCH 23390 binds to a 5hydroxytryptamine (5-HT) site in vitro, its affinity for the D-1 site is about 25 times higher than for 5-HT (11). Moreover, doses of $\mathrm{SCH} 23390$ from $40-200 \mu \mathrm{g} / \mathrm{kg}$ had no inhibitory effect on the typical serotonergic behavioral syndrome induced by 5-methoxy$\mathrm{N}, \mathrm{N}$-dimethyltryptamine (19). Thus, it is unlikely that a serotonergic mechanism is involved in potentiation of opioid analgesia by $\mathrm{SCH} 23390$, since doses used in these studies were less than $200 \mu \mathrm{g} / \mathrm{kg}$. Eticlopride displays little affinity for serotonergic, adrenergic, histaminergic or muscarinic receptors in vitro (9). 2) The dopaminergic system interacting with the opioid analgesic 
mechanism might be maximally activated under basal conditions, rendering dopaminergic agonists apparently ineffective against morphine. As suggested by Kamata and co-workers (13), inhibition of opioid analgesia by dopamine agonists may only be unmasked by treatments, such as chronic neuroleptic administration, which cause up-regulation of doamine receptors and consequently a supersensitivity of the dopamine system.

Recently, Schoffelmeer and co-workers have demonstrated that opioids inhibit dopamine-stimulated cAMP release from slices of rat neostriatum $(22,23)$. The effect of delta opioid agonists is strongly protentiated in the presence of sulpiride, a D-2 selective antagonist. The authors suggest that D-2 receptor antagonism in neostriatum enhances the inhibitory effect on cAMP of delta, but not mu, opioids by inducing a coupling between the delta opioid receptor and dopamine-sensitive adenylate cyclase. Although sulpiride had no effect on morphine's inhibitory effect on dopamine-induced cAMP release from striatal slices, it is interesting to speculate that a similar coupling may occur between the analgesic and cataleptic mu-opioid receptors and adenylate cyclase in other brain regions, which might account for the enhanced analgesic and cataleptic effects of morphine in the presence of D-1 or D-2 receptor antagonists reported here.

\section{ACKNOWLEDGEMENTS}

This work was supported in part by grants from the Veterans Administration and the National Institute of Health (Grant No. DK-37669) to L.C.T. and training grant No. 5-T32-NS07222 to J.A.K-R.

\section{REFERENCES}

1. Apud, J. A.; Masotto, C.; Ongini, E.; Racagni, G. Interaction of SCH 23390, a D-1-selective antagonist, with the anterior pituitary D-2 receptors and prolactin secretion in the rat. Eur. J. Pharmacol. $112: 187-193 ; 1985$

2. Balsara, J. J.; Nandal, N. V.; Burte, N. P.; Jadhav, J. H.; Chandorkar, A. G. Effects of naloxone on methamphetamine and apomorphine stereotypy and on haloperidol catalepsy in rats. Psychopharmacology (Berlin) 82:237-240; 1984

3. Billard,W.; Ruperto, V.; Crosby, G.; Iorio, L. C.; Barnett, A. Characterization of the binding of ${ }^{3} \mathrm{H}-\mathrm{SCH} 23390$, a selective D-1 receptor antagonist ligand, in rat striatum. Life Sci. 35:1885-1893; 1984.

4. Boyson, S. J.; McGonigle, P.; Molinoff, P. B. Quantitative autoradiographic localization of the D1 and D2 subtypes of dopamine receptors in rat brain. J. Neurosei. 6:3177-3188; 1986.

5. Costall, B.: Naylor, R. J. On catalepsy and catatonia and the predictability of the catalepsy test for neuroleptic activity. Psychopharmacologia 34:233-241; 1974.

6. dePaulis, T.; Kumar, Y.; Johansson, L.; Ramsby, S.: Hall, H.; Sallemark, M.; Angeby-Moller, K.; Ogren, S.-O. Potential neuroleptic agents. 4. Chemistry, behavioral pharmacology, and inhibition of $\left[{ }^{3} \mathrm{H}\right]$ spiperone binding of 3,5-disubstituted $\mathrm{N}-[$ ( 1 -ethyl-2-pyrrolidinyl)methyl $]-$ 6-methoxysalicylamides. J. Med. Chem. 29:61-69: 1986.

7. Eidelberg. E.; Erspamer, R. Dopaminergic mechanisms of opiate actions in brain. J. Pharmacol. Exp. Ther. 192:50-57; 1975.

8. Fog, R. On stereotypy and catalepsy: studies on the effect of amphetamines and neuroleptics in rats. Acta Neurol. Scand. [Suppl.] $50: 3-66 ; 1972$

9. Hall, H.; Kohler, C.; Gawell, L. Some in vitro receptor binding properties of $\left[{ }^{3} \mathrm{H}\right]$ eticlopride, a novel substituted benzamide, selective for dopamine-D2 receptors in the rat brain. Eur. J. Pharmacol. 111:191-199:1985.

10. Halpern, B. C.; Halverson. J. D. Modification of escape from noxious stimuli after bulbar reticular formation lesions. Behav. Biol. 11 215-229; 1974.

11. Hyttel, J. SCH 23390-The first selective dopamine D-1 antagonist. Eur. J. Pharmacol. 91:153-154; 1983.

12. Iorio, L. C.; Barnett, A.; Leitz, F. H.; Houser, V. P.; Korduba, C. A. SCH 23390 , a potential benzazepine antipsychotic with unique interactions on dopaminergic systems. J. Pharmacol. Exp. Ther. 226 462-468: 1983 .

13. Kamata. K.; Ogawa, K.; Noma, S.; Kameyama. T. Effects of apomorphine on morphine analgesia during the state of dopaminergic supersensitivity after chronic treatment with haloperidol. J. Pharmacobiodyn. 9:88-94; 1986.

14. Kebabian, J. W.; Calne, D. B. Multiple receptors for dopamine Nature 227:93-96; 1979 .

15. Magnusson, O.; Fowler, C. J.; Kohler, C.; Ogren, S-O. Dopamine D2 receptors and dopamine metabolism: relationship between bio- chemical and behavioral effects of substituted benzamide drugs. Neuropharmacology 25:187-197; 1986.

16. O'Boyle, K. M.; Waddington, J. L. Selective and stereospecific interactions of R-SK\&F 38393 with $\left[{ }^{3} \mathrm{H}\right]$ piflutixol but not $\left[{ }^{3} \mathrm{H}\right]$ spiperone binding to striatal D1 and D2 dopamine receptors: comparisons with SCH 23390. Eur. J. Pharmacol. 98:433-436; 1984.

17. O'Callaghan, J. P.; Holtzman, S. G. Quantification of the analgesic activity of narcotic antagonists by a modified hot-plate procedure. J. Pharmacol. Exp. Ther. 192:497-505; 1975.

18. Pert, A.; Yaksh, T. Localization of the antinociceptive action of morphine in primate brain. Pharmacol. Biochem. Behav. 3:133-138; 1975

19. Pugh, M. T.; O’Boyle, K. M.; Molloy, A. G.; Waddington, J. L. Effects of the putative D-1 antagonist SCH 23390 on stereotyped behavior induced by the D-2 agonist RU 24213. Psychopharmacology (Berlin) 87:308-312; 1985

20. Rondeau, D. B.; Turcotte, M.; Young, L.; Hebert, D. Similarities of the cataleptic state induced by $\beta$-endorphin and morphine. Pharmacol. Biochem. Behav. 17:703-707: 1982.

21. Samanin, R.; Bernasconi, S. Effects of intraventricularly injected 6-OH dopamine or midbrain raphe lesion on morphine analgesia in rats. Psychopharmacologia 25:175-182; 1972 .

22. Schoffelmeer, A. N. M.; Hansen, H. A.; Stoof, J. C.; Mulder, A. H Inhibition of dopamine-stimulated cyclic AMP efflux from rat neostriatal slices by activation of $\mathrm{mu}$ and delta-opioid receptors: a permissive role for D-2 dopamine receptors. Eur. J. Pharmacol. 118:363-366; 1985

23. Schoffelmeer, A. N. M.: Hansen, H. A.: Stoof, J. C.: Mulder, A. H Blockade of D-2 dopamine receptors strongly enhances the potency of enkephalins to inhibit dopamine-sensitive adenylate cyclase in rat neostriatum: involvement of delta- and mu-opioid receptors. J. Neurosei. $6: 2235-2239 ; 1986$.

24. Schulz, D. W.; Wyrick, S. D.; Mailman, R. B. $\left[{ }^{3} \mathrm{H}\right] \mathrm{SCH} 23390$ has the characteristics of a dopamine receptor ligand in the rat central nervous system. Eur. J. Pharmacol. 106:211-212: 1984.

25. Schulz, D. W.; Stanford, E. J.; Wyrick, S. W.: Mailman, R. B. Binding of $\left[{ }^{3} \mathrm{H}\right] \mathrm{SCH} 23390$ in rat brain: regional distribution and effects of assay conditions and GTP suggest interactions at a $D_{1}$-like dopamine receptor. J. Neurochem. 45:1601-1611; 1985.

26. Stoof, J. C.; Kebabian, J. W. Opposing roles for D-1 and D-2 dopamine receptors in efflux of cyclic AMP from rat neostriatum. Nature 294:366-368: 1981

27. VanderWende, C.; Spoerlein. M. T. Role of dopaminergic receptors in morphine analgesia and tolerance. Res. Commun. Chem. Pathol. Pharmacol. 5:35-43; 1973.

28. Yaksh, T. L.; Rudy, T. A. Narcotic analgesics: CNS sites and mechanisms of action as revealed by intracerebral injection techniques. Pain 4:299-359; 1978 